\title{
Cecropin A-melittin mutant is a potential therapeutic agent in treating bacterial gastroenteritis
}

\author{
Shengyue $\mathrm{Ji}^{1,{ }^{*}}$, Liang Chen ${ }^{1, *}$, Weili $\mathrm{Li}^{1}$, Xiangfang Tang ${ }^{1}$, Qingshi Meng ${ }^{1}$ and Hongfu \\ Zhang $^{1}$ \\ ${ }^{1}$ Key Laboratory of Animal Nutrition, Institute of Animal Sciences, Chinese Academy of Agricultural Sciences, Beijing 100193, \\ China \\ *These authors contributed equally to this work \\ Correspondence to: Hongfu Zhang, email: zhanghongfu2016@163.com
}

Keywords: CAM-W; in vitro cytotoxicity; acute oral toxicity test; bioavailability

Received: October 16, $2017 \quad$ Accepted: December 01, 2017 Published: December 22, 2017

Copyright: $\mathrm{Ji}$ et al. This is an open-access article distributed under the terms of the Creative Commons Attribution License 3.0 ( CC BY 3.0), which permits unrestricted use, distribution, and reproduction in any medium, provided the original author and source are credited.

\section{ABSTRACT}

Cecropin A-melittin mutant (CAM-W) is a novel antimicrobial peptide with promising proteolytic stability and in vitro activity against bacteria and fungi associated with gastroenteritis. To assess the clinical value of CAM-W for treatment of bacterial gastroenteritis, we tested CAM-W in a HT-29 cell line model and a Kunming murine model challenged with Shiga toxin-producing $E$. coli (STEC) strains. Our results showed that CAM-W is $100 \%$ protective in Kunming mice challenged with STEC strains. Moreover, CAM-W exhibited only moderate cytotoxicity against HT-29 cells (IC50 > $300 \mathrm{mg} / \mathrm{L})$, and oral administration of a single dose of CAM-W (5000 mg/ $\mathrm{kg})$ caused no observable side effects in mice. Notably, little if any CAM-W entered the bloodstream of treated mice. These findings demonstrate the potential utility of CAM-W for treatment of bacterial gastroenteritis and provide a basis for further investigation.

\section{INTRODUCTION}

The re-emergence of gastroenteritis caused by multidrug-resistant bacteria presents a serious challenge to clinicians [1], and the development of novel treatment strategies is needed. The use of antimicrobial peptides (AMPs) offers a potential chemotherapeutic strategy to target drug-resistant bacterial pathogens [2-5]. A fourtryptophan-substitution mutant (KWKLWKKIEKWGQ GIGAVLK $\boldsymbol{W} L T T \boldsymbol{W} L-\mathrm{NH}_{2}$; CAM-W) [6] from cecropin A-melittin (KWKLFKKIEKVGQGIGAVLKVLTTGL$\mathrm{NH}_{2}$; CAM) [7] has recently been developed through the replacement of specific amino acid residues by four tryptophans (W). Compared with its parent peptide CAM, $\mathrm{CAM}-\mathrm{W}$ displays a more potent antimicrobial activity against a wide range of important clinical bacterial and fungal pathogens in vitro, such as Escherichia coli and Aspergillus flavus, and also shows an improved proteolytic stability under a series of proteases including trypsin, pepsin and Staphylococcusaureus
V8 protease, which is commonly present in the gastrointestinal tract [6]. In addition, the $\mathrm{pH}$ range in the gastrointestinal tract appears to be suitable for the function of CAM-W [6]. Thus, it is suggested that CAM-W has potential as a therapeutic agent in treating bacterial gastroenteritis.

Like other biosynthesized AMPs, such as sublancin $[8,9]$ and cecropin AD [10], CAM-W was just recently recombinantly produced in a Bacillus subtilis host [11]. The present study investigated the potential of recombinant $\mathrm{CAM}-\mathrm{W}$ in treating bacterial gastroenteritis, including the in vitro cytotoxicity towards a human colorectal adenocarcinoma cell line HT-29, acute oral toxicity, the bioavailability, and the in vivo antibacterial activity using a Shiga toxin-producing E. coli (STEC) infection mice model. In this study, we used an improved streptomycin-treated STEC oral infection mice model, which was developed after oral administration with only about $5 \times 10^{3} \mathrm{CFU}$ of STEC followed by multiple mitomycin $\mathrm{C}$ (MMC) treatment [12]. 


\section{MATERIALS AND METHODS}

\section{HT-29 lytic activity}

The human colorectal adenocarcinoma cell line HT-29 was obtained from ATCC (Rockville, USA) and cultured in RPMI-1640 medium (Invitrogen, USA) supplemented with $0.2 \mathrm{~g} / \mathrm{L}$ streptomycin, $0.1 \mathrm{~g} / \mathrm{L}$ penicillin, $10 \%$ heat-inactivated fetal calf serum (FCS, Germany). Cells were maintained at $37^{\circ} \mathrm{C}$ in $5 \% \mathrm{CO}_{2}$. For the assays, the HT-29 cells were first starved for $24 \mathrm{~h}$ in serum-free medium and then were seeded in a 24-well plate (Nunc, Germany) at $1 \times 10^{5}$ cells/well. At subconfluency, the medium was replaced, and the cells were incubated with serial CAM-W dilutions (CAM-W sample was obtained by using the recombinant Bacillus subtilis strain stored in our laboratory with reported method [11]) of 300 , $150,75,40,20,10,5,2.5,1.2,0.6$, and $0.3 \mathrm{mg} / \mathrm{L}$ in a volume of $100 \mu \mathrm{l}$ for $24 \mathrm{~h}$ [13]. Cell viability was assessed in exposed cultures by using a colorimetric 3-(4,5dimethylthiazol-2-yl)-2,5 diphenyl tetrazolium thiazolyl blue assay (MTT, Roche Diagnostics, Germany). The reaction samples were detected at $570 \mathrm{~nm}$ with a microtiter ELISA reader (Epoch ${ }^{\mathrm{TM}}$, BioTek- ${ }^{\circledR}$ instruments, Inc., USA).

\section{Animals and preparation of CAM-W solution}

Experiments were conducted using Chinese Kunming mice (Kunming Institute of Zoology, Chinese), weighing $20 \pm 2 \mathrm{~g}$. Animals were housed in stainless steel cages by gender in a ventilated animal room with temperature and relative humidity of $22 \pm 2^{\circ} \mathrm{C}$ and $55 \pm 10 \%$, respectively, in a $12 \mathrm{~h} \mathrm{light/dark} \mathrm{cycle} \mathrm{for} 7$ days prior to treatments. Sterilized food and distilled water for mice were available ad libitum. All experiments in this section were approved by the Animal Ethical Committee of the Chinese Academy of Agricultural Sciences (Beijing, China). Appropriate amounts of CAM-W was dissolved in a vehicle of $5 \%$ ethanol $/ 5 \%$ Cremophor $\mathrm{EL} / 0.9 \% \mathrm{NaCl}$ aqueous solution to a concentration of $100 \mathrm{mg} / \mathrm{ml}$, which was further diluted with vehicle to an appropriate concentration according to the requirements of the experiment.

\section{Acute oral toxicity}

According to Table 1, 60 Kunming mice were randomly divided into 5 groups (half males and half females in each group). Groups I, II, III and IV were orally administered with single doses of 500, 1000, 2000 or 5000 $\mathrm{mg} / \mathrm{kg}$ body weight and were monitored for 2 weeks. The control group was administrated the vehicle solution. The volume of $0.5 \mathrm{ml}$ solution was used in all treatments. At the end of the experiments, the viscera (heart, lungs, kidneys, liver, thymus, spleen, and stomach) of mice were weighed immediately after euthanization. Pathological changes in visceral organs were observed. Mean organ- to-terminal body weight ratios were calculated against fasting body weight. Biochemical parameters were examined using Modular analytics (Roche, Germany), including alanine amino transferase (ALT), albumin (Alb), alkaline phosphatase (ALP), aspartate amino transferase (AST), blood urea nitrogen (BUN), creatinine (Cre), globulin (GB), total cholesterol (TC), total protein (TP), and triglyceride (TG). This part of the experiments was conducted in accordance with the guidelines of the Organization for Economic Cooperation and Development (OECD, 2007).

\section{Oral bioavailability}

A single dose of CAM-W $(50 \mathrm{mg} / \mathrm{kg})$ was administrated to 60 mice (half males and half females) in the experiment group, and vehicle solution was administrated to 60 mice ( 30 males and 30 females) in the control group. Blood samples were collected from the retro-orbital venous plexus in heparinized tubes under diethyl ether anaesthesia at $0.5,1,2,3,4,6,8,12,16$ and $20 \mathrm{~h}$ after drug oral administration, using 6 mice (half males and half females) per time point. Blood was centrifuged at $2000 \times \mathrm{g}$ for $10 \mathrm{~min}$, and the plasma fraction was separated and stored at $-20^{\circ} \mathrm{C}$ for further use.

\section{Determination of CAM-W concentration in blood}

CAM-W concentration in blood samples was determined by RP-HPLC with an analytical Zorbax 300SB$\mathrm{C} 8$ column using the procedure as described above. The determined concentration of purified CAM-W solution was used as a standard. The area under plasma concentrationtime curve (AUC) was calculated by the linear trapezoidal rule without extrapolation to infinity, and the standard deviation (SD) of the AUC was calculated with the law of propagation of errors.

\section{Antibacterial activity in vivo}

A clinically isolated streptomycin-resistant STEC O157:H7 strain capable of producing both Stx1 and Stx2 was used as an indicator strain in antibacterial activity of CAM-W in a STEC gastrointestinal infection mice model [12] that was developed as reported [14]. After overnight growth at $37^{\circ} \mathrm{C}$ in Casamino Acids-yeast extract broth [15], the indicator strain was suspended in sterile saline at $5 \times 10^{4} \mathrm{CFU} / \mathrm{ml}$. Following that, mice in each group were orally administrated with $100 \mu \mathrm{l}$ of indicator strain suspension. At 18, 21, and $24 \mathrm{~h}$ after STEC oral administration, when as much as $10^{9} \mathrm{CFU}$ STEC was obtained from $1 \mathrm{~g}$ fecal excretion, $0.25 \mathrm{mg} / \mathrm{kg}$ body weight of MMC (Sigma, USA) in total, was intraperitoneally administrated 3 times per day [12]. In the experiment group, CAM-W $(10 \mathrm{mg} / \mathrm{kg})$ was orally administrated to every mouse (10 males and 10 females) 3 times per day $24 \mathrm{~h}$ after STEC oral 
Table 1: Effect of CAM-W on body weight, death rate, and coefficients of different organs

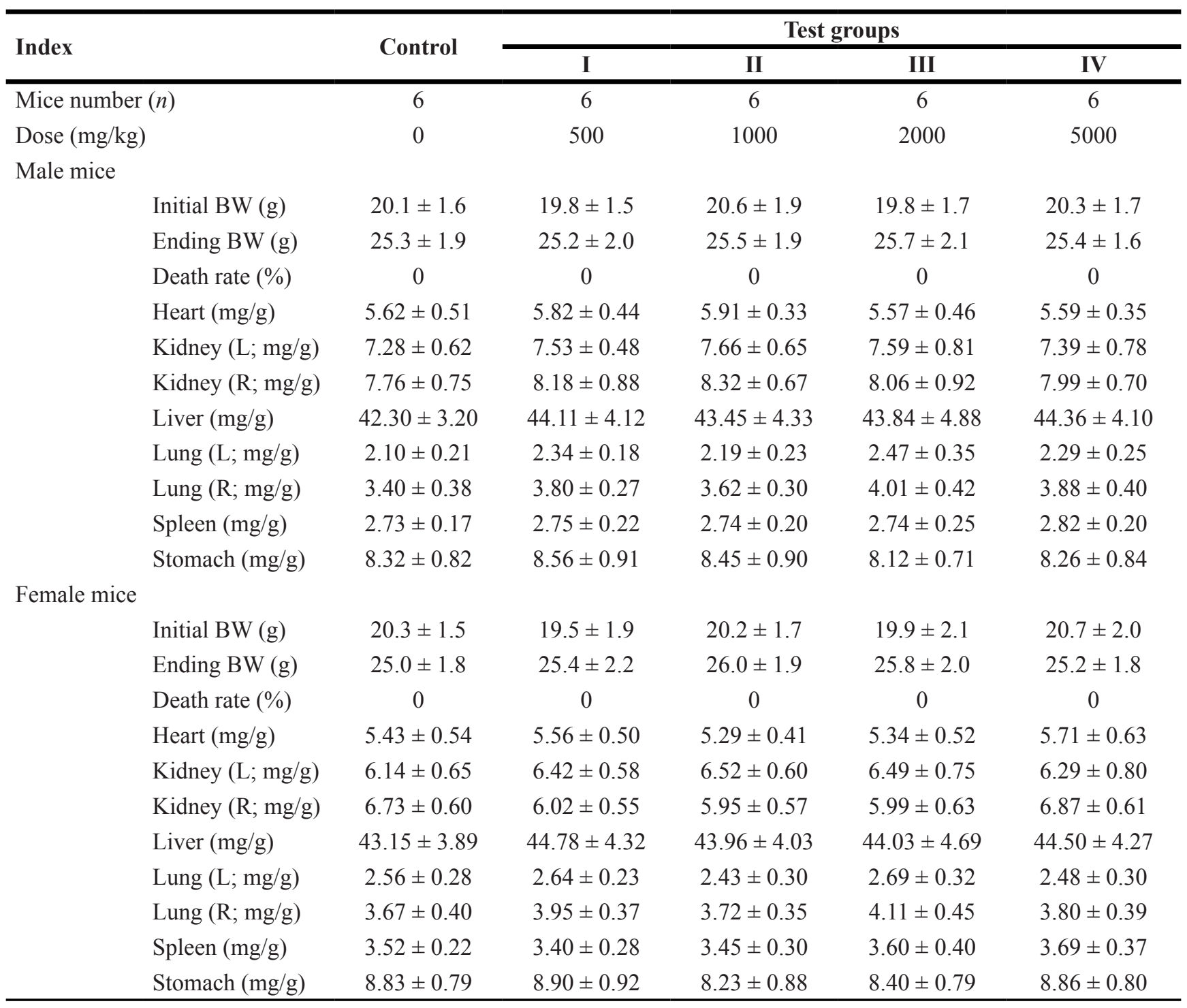

administration for 15 days. The control group (10 males and 10 females) was administrated the vehicle solution 3 times per day. Drinking water was dissolved with streptomycin sulfate (Sigma, USA) at a concentration of $5 \mathrm{mg} / \mathrm{ml}$. For counting the viable STEC number in feces, fresh samples were aseptically collected from experimental mice, homogenized in $1 \mathrm{ml}$ sterile saline solution and subsequently cultured on sorbitol-MacConkey agar (Difco, USA). The amount of viable STEC was counted by culturing them at $37^{\circ} \mathrm{C}$ for $24 \mathrm{~h}$ on sorbitol-MacConkey agar supplemented with $2.5 \mathrm{mg} / \mathrm{ml}$ of cefixime (Sigma, USA) and $0.05 \mathrm{mg} / \mathrm{ml}$ of potassium tellurite (Sigma, USA).

\section{Antibacterial activity in vitro}

The streptomycin-resistant STEC O157:H7 strain was used as an indicator strain. A minimum inhibitory concentration (MIC) assay was performed and depended on a microtiter broth dilution method as described [16], with slight modification. Deionized water, $0.1 \mathrm{M} \mathrm{NaOH}, 2 \mathrm{M} \mathrm{NaCl}, 70 \%$ ethanol, and 10 $\mathrm{mM}$ Tris buffer ( $\mathrm{pH}$ 7.4) were used to pre-equilibrate a volume packed with DEAE-Sephacel (Sigma-Aldrich, Schnelldorf, Germany), to which $100 \mathrm{~mL}$ of LuriaBertani (LB) broth medium in the same Tris buffer was applied twice to prepare the refined medium. The peptide samples were dissolved into Tris buffer to prepare the required tenfold serial dilutions. The overnight culture of indicator strain was washed twice with Tris buffer and then diluted to approximately $5 \times 10^{5} \mathrm{CFU} / \mathrm{mL}$ in refined medium. The wells of a 96 -well microtiter plate were filled with aliquots of $90 \mu \mathrm{L}$ of bacterial solution. Thereafter, aliquots of $10 \mu \mathrm{L}$ of above tenfold peptide dilutions were placed into the corresponding wells, yielding serial working concentrations of $64,32,16,8$, $4,2,1,0.5,0.25,0.12$, and $0.06 \mathrm{mg} / \mathrm{L}$. The mixtures were 
incubated at $37^{\circ} \mathrm{C}$ for $21 \mathrm{~h}$, and the result was determined using a described method [17]. Meanwhile, a negative control was set up by adopting an identical reaction system without peptide solution. MIC was defined as the lowest concentration required for inhibiting bacterial growth by more than $90 \%$ after overnight incubation.

\section{Statistical analysis}

Statistical difference was established using the Student's $t$-test to compare with control. The mean \pm standard deviation (SD) was used as the mean value. Values of $P<0.05$ were considered statistically significant.

\section{RESULTS}

\section{In vitro HT-29 lytic activity and antibacterial activity}

CAM-W was evaluated for its in vitro cell lytic activity using the human colorectal adenocarcinoma cell line, HT-29. Under CAM-W treatment, the \% of lysed HT-29 cells was no more than $20 \%$. The maximum lysis rate was $19.22 \%$ when treated with $300 \mathrm{mg} / \mathrm{L}$ of CAM-W (Figure 1), indicating that the $\mathrm{IC}_{50}$ of CAM-W against HT-29 cells was more than 300 $\mathrm{mg} / \mathrm{L}$. In addition, CAM-W displayed potent antibacterial activity against the streptomycin-resistant STEC O157:H7 strain, with a MIC of $0.3 \pm 0.10 \mathrm{mg} / \mathrm{L}$.

\section{Acute oral toxicity test}

All mice in all groups survived when CAM-W was orally administrated. Physical signs of toxicity, such as abnormal breathing, movement and stool, were also not observed. As shown in Table 1, no statistically significant changes in body weight existed between the treated and control groups. In addition, no significant changes in organ/body weight ratios were observed in any of the organ weights between treated and control groups.

With regard to the biochemical marker BUN, the $5000 \mathrm{mg} / \mathrm{kg}$ treated mice showed a statistically significant increase versus the control group (Table 2). No other biochemical marker showed in a significanct difference between treated and control groups. In addition, no visible histopathological changes in visceral organs were observed between treated and control groups.

\section{Oral bioavailability}

The CAM-W concentrations in blood plasma from 3 female and 3 male mice were determined at 10 time points within $20 \mathrm{~h}$ following consumption of CAM-W (50 $\mathrm{mg} / \mathrm{kg}$ ). CAM-W was not detectable at any of the 10 time points throughout the $20 \mathrm{~h}$ duration (data not shown). Notably, the peak of CAM-W was not detected by our RP-HPLC system.

\section{In vivo antibacterial activity}

A murine model of STEC gastrointestinal infection was used to assess the in vivo antibacterial activity of CAM-W. The STEC excretion levels in feces after the oral infection of $5 \times 10^{3} \mathrm{CFU} /$ body confirmed a dramatic proliferation of STEC in the gastrointestinal tracts within $24 \mathrm{~h}$ (Figure 2A). CAM-W was orally administered everyday for 14 days. CAM-W could significantly inhibit

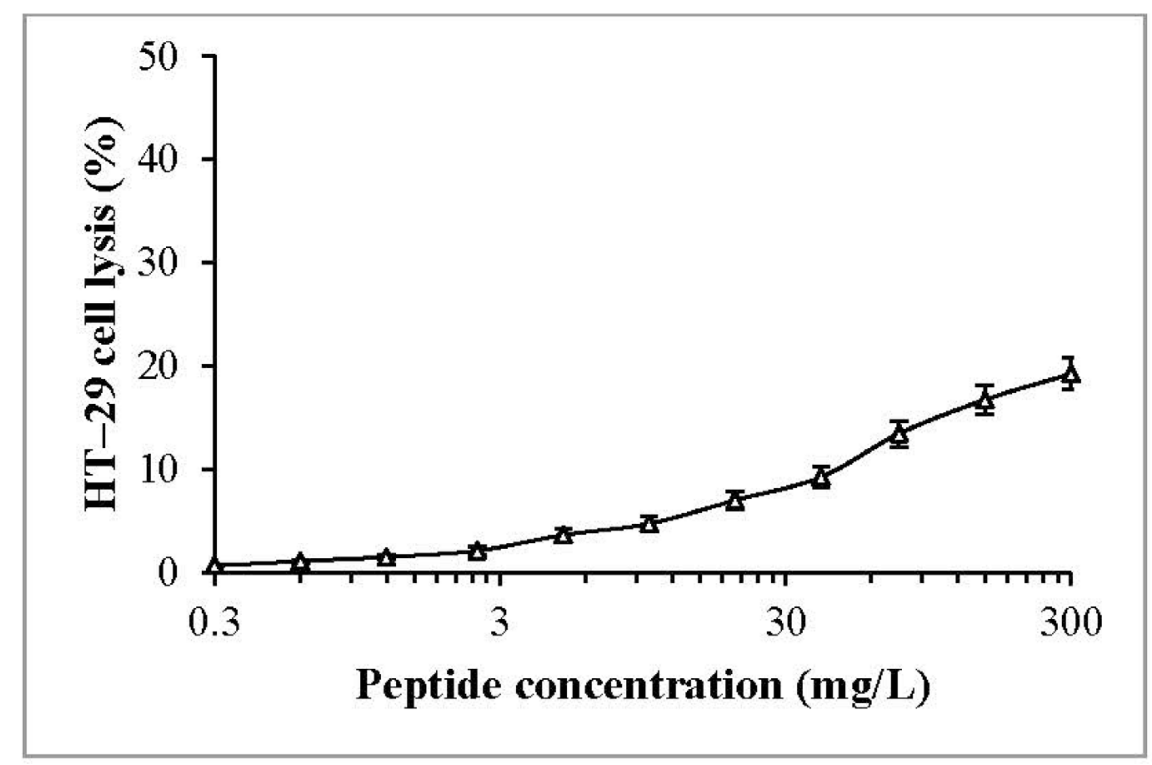

Figure 1: HT-29 cell viability treated by a series of CAM-W dilutions, in working concentrations of 300, 150, 75, 40, 20, 10, 5, 2.5, 1.2, 0.6, and $0.3 \mathrm{mg} / \mathrm{L}$, at $37^{\circ} \mathrm{C}$ for $24 \mathrm{~h}$. The data points show the means, and error bars show the standard deviations of three independently generated data points. 
Table 2: Biochemical parameters of treated mice after a single oral dose of CAM-W

\begin{tabular}{|c|c|c|c|c|c|}
\hline \multirow{2}{*}{ Index } & \multirow{2}{*}{ Control } & \multicolumn{4}{|c|}{ Test groups } \\
\hline & & I & II & III & IV \\
\hline \multicolumn{6}{|l|}{ Male mice } \\
\hline $\mathrm{Alb}(\mathrm{g} / \mathrm{L})$ & $31.5 \pm 2.1$ & $32.2 \pm 2.3$ & $32.8 \pm 2.0$ & $33.1 \pm 2.1$ & $32.4 \pm 2.4$ \\
\hline ALT (U/L) & $30.1 \pm 2.3$ & $29.4 \pm 2.0$ & $29.8 \pm 1.9$ & $30.5 \pm 3.1$ & $28.9 \pm 2.9$ \\
\hline ALP (U/L) & $138.4 \pm 10.1$ & $139.5 \pm 9.8$ & $140.9 \pm 11.5$ & $142.0 \pm 12.2$ & $141.6 \pm 12.4$ \\
\hline AST (U/L) & $62.3 \pm 3.4$ & $65.8 \pm 5.6$ & $60.4 \pm 4.9$ & $65.0 \pm 5.3$ & $68.7 \pm 6.0$ \\
\hline $\mathrm{BUN}(\mathrm{mmol} / \mathrm{L})$ & $4.9 \pm 2.0$ & $5.1 \pm 2.2$ & $5.3 \pm 3.0$ & $6.5 \pm 2.8$ & $10.4 \pm 2.5^{*}$ \\
\hline $\mathrm{Cre}(\mu \mathrm{mol} / \mathrm{L})$ & $29.32 \pm 2.35$ & $29.44 \pm 2.53$ & $30.12 \pm 2.91$ & $29.56 \pm 2.69$ & $29.83 \pm 2.80$ \\
\hline GB $(\mathrm{g} / \mathrm{L})$ & $19.3 \pm 2.3$ & $18.2 \pm 1.5$ & $19.4 \pm 2.0$ & $20.0 \pm 1.9$ & $19.5 \pm 2.3$ \\
\hline $\mathrm{TC}(\mathrm{mmol} / \mathrm{L})$ & $3.73 \pm 0.29$ & $3.94 \pm 0.43$ & $3.82 \pm 0.33$ & $3.89 \pm 0.42$ & $3.76 \pm 0.31$ \\
\hline $\mathrm{TP}(\mathrm{g} / \mathrm{L})$ & $51.2 \pm 4.8$ & $50.9 \pm 5.2$ & $53.3 \pm 5.8$ & $50.0 \pm 4.9$ & $52.2 \pm 5.4$ \\
\hline $\mathrm{TG}(\mathrm{mmol} / \mathrm{L})$ & $2.13 \pm 0.04$ & $2.25 \pm 0.05$ & $2.04 \pm 0.03$ & $2.11 \pm 0.04$ & $2.24 \pm 0.03$ \\
\hline \multicolumn{6}{|l|}{ Female mice } \\
\hline Alb (g/L) & $35.3 \pm 2.5$ & $34.2 \pm 2.8$ & $36.0 \pm 3.2$ & $37.3 \pm 3.5$ & $36.4 \pm 3.3$ \\
\hline ALT (U/L) & $63.4 \pm 25.6$ & $48.3 \pm 18.0$ & $52.8 \pm 22.2$ & $56.3 \pm 26.7$ & $51.0 \pm 19.5$ \\
\hline ALP (U/L) & $123.0 \pm 15.3$ & $126.8 \pm 14.5$ & $128.0 \pm 12.9$ & $130.3 \pm 12.0$ & $133.3 \pm 13.4$ \\
\hline AST (U/L) & $137.8 \pm 29.5$ & $128.9 \pm 24.8$ & $125.0 \pm 35.1$ & $122.6 \pm 34.8$ & $130.4 \pm 24.1$ \\
\hline $\mathrm{BUN}(\mathrm{mmol} / \mathrm{L})$ & $5.04 \pm 0.83$ & $6.28 \pm 0.07$ & $6.38 \pm 0.07$ & $7.49 \pm 0.06$ & $10.72 \pm 0.08^{*}$ \\
\hline $\mathrm{Cre}(\mu \mathrm{mol} / \mathrm{L})$ & $41.67 \pm 0.52$ & $40.35 \pm 0.48$ & $41.53 \pm 0.42$ & $41.68 \pm 0.50$ & $41.70 \pm 0.53$ \\
\hline GB (g/L) & $15.0 \pm 2.3$ & $15.3 \pm 1.9$ & $15.8 \pm 2.0$ & $16.2 \pm 1.7$ & $16.5 \pm 2.4$ \\
\hline $\mathrm{TC}(\mathrm{mmol} / \mathrm{L})$ & $2.39 \pm 0.11$ & $2.18 \pm 0.15$ & $2.26 \pm 0.18$ & $2.31 \pm 0.20$ & $2.43 \pm 0.23$ \\
\hline $\mathrm{TP}(\mathrm{g} / \mathrm{L})$ & $50.3 \pm 3.5$ & $50.8 \pm 3.1$ & $51.2 \pm 4.1$ & $51.9 \pm 5.3$ & $53.0 \pm 4.9$ \\
\hline $\mathrm{TG}(\mathrm{mmol} / \mathrm{L})$ & $2.18 \pm 0.14$ & $1.98 \pm 0.10$ & $2.03 \pm 0.12$ & $2.10 \pm 0.16$ & $1.99 \pm 0.13$ \\
\hline
\end{tabular}

Abbreviations: ALT, alanine amino transferase; Alb, albumin; ALP, alkaline phosphatase; AST, aspartate amino transferase; BUN, blood urea nitrogen; Cre, creatinine; GB, globulin; TC, total cholesterol; TP, total protein; TG, triglyceride.

the further colonization of STEC once its proliferation reached a plateau (Figure 2A). In the control group, body weights decreased dramatically (Figure 2B), and 18 of the 20 mice died within 14 days after MMC treatment (Figure 2C). In contrast, in the CAM-W-treated group, body weights were stable (Figure 2B) and no mortality was observed throughout the observational period (Figure 2C).

\section{DISCUSSION}

CAM-W demonstrates a moderate cytotoxicity $\left(\mathrm{IC}_{50}>300 \mathrm{mg} / \mathrm{L}\right)$ in an erythrocyte viability test, a potent antimicrobial activity and also overcomes several challenges under various conditions, involving specific temperatures $(20,30,40,50,60,70,80$, and $90 \mathrm{C}), \mathrm{pH}$ values $(2.0,3.0$, 4.0, 5.0, 6.0, 7.0, 8.0, and 9.0), and proteases (trypsin, pepsin, human neutrophil elastase, Pseudomonas aeruginosa elastase, and Staphylococcus aureus V8 protease) [6]. This suggests CAM-W having a potential in serving as an alternative to conventional antibiotics against bacterial gastroenteritis. In this work, CAM-W displayed an antibacterial activity with a MIC of $0.3 \pm 0.10 \mathrm{mg} / \mathrm{L}$ toward streptomycin-resistant STEC O157:H7 strain, which is consistent with the MICs ranged from 0.3 to $1.0 \mathrm{mg} / \mathrm{L}$ against Gram-negative bacteria reported in the literature [6]. Meanwhile, $\mathrm{IC}_{50}$ of more than $300 \mathrm{mg} / \mathrm{L}$ towards human colorectal adenocarcinoma cell line HT-29 indicates CAM-W having a low cytotoxicity [13]. All these reveals the medicinal value of CAM-W.

In a 15-day study, CAM-W was orally administered once to both male and female mice at single doses of 500 , 1000,2000 , and $5000 \mathrm{mg} / \mathrm{kg}$, according to the OECD guidelines (OECD, 2007). CAM-W administration neither demonstrated any clinical signs nor caused mortality. In addition, BUN levels in $5000 \mathrm{mg} / \mathrm{kg}$ of CAM-Wtreated mice compared with that in the control group showed statistically significant increases but remained in the normal range $(4.63-11.75 \mathrm{mmol} / \mathrm{L})$ [17]. This result indicates that $\mathrm{CAM}-\mathrm{W}$ increased the end product of protein metabolism but was not toxic to the kidneys. Therefore, a single oral dose of CAM-W did not induce 

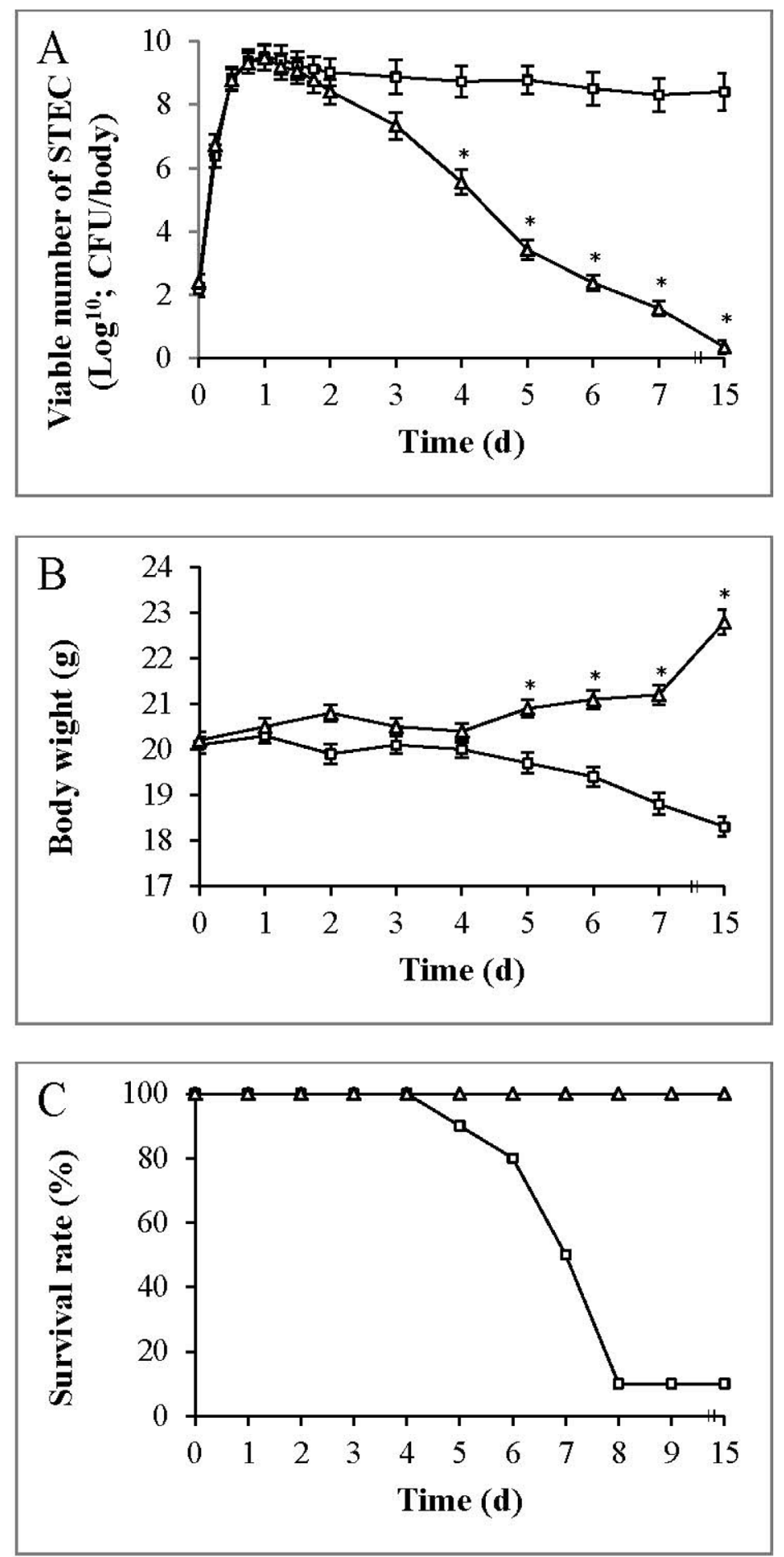

Figure 2: Inhibition of STEC infections by CAM-W in Kunming mice. 18, 21 and $24 \mathrm{~h}$ after STEC $\left(5 \times 10^{3} \mathrm{CFU}\right)$ oral administration on day $0,0.25 \mathrm{mg} / \mathrm{kg}$ body weight of multiple mitomycin $\mathrm{C}$, in total, was intraperitoneally administrated in three times. CAM-W solution at dose levels of $10 \mathrm{mg} / \mathrm{kg}$ body weight was orally administrated to 10 mice (5 males and 5 females) three times a day in the experiment group $24 \mathrm{~h}$ after STEC oral administration until day 15, and control group, composed by 5 males and 5 females, was administrated also three a day with the vehicle solution. (A) STEC strain number-counting for excretion feces in both experiment and control group mice on $0,6,12,18,24,30,36,48 \mathrm{~h}$, and on day from 3 until 15 after the STEC infection, using the method as described in the text. Symbols: ( $\square$ ) number of STEC strain in STEC infected control group. ( $\Delta$ ) number of STEC strain in CAM-W-treated mice group; (B) All mice in both STEC-infected mice control group $(\square)$ and CAM-W-treated mice group $(\Delta)$ were weighed once a day until day 15. (C) Survival rates in both STEC-infected group ( $\square$ ) and CAM-W-treated group $(\Delta)$ were observed from day 0 until 15 after STEC oral administration. "indicated a statistically significant difference of CAM-W-treated group from the control group $(P<0.05)$. 
any harmful effects, and the $\mathrm{LD}_{50}$ of orally administered CAM-W was higher than $5000 \mathrm{mg} / \mathrm{kg} / \mathrm{d}$ in both sexes.

Blood samples analysis after single-dose intragastric administration revealed that CAM-W did not reach detectable levels in the bloodstream within 20 hours. The absence of CAM-W in the blood reflects poor bioavailability of this novel AMP. Together, both oral bioavailability and acute oral toxicity tests demonstrated that CAM-W can barely enter into the bloodstream of treated mice in its intact form.

CAM-W was assessed as a treatment for mice with streptomycin depleted the facultative intestinal flora, which appeared to allow for explosive opportunistic proliferation of streptomycin-resistant STEC strains (Figure 2A). CAM-W showed to be $100 \%$ protective to Kunming mice challenged with streptomycin-resistant STEC strains. The effective dose of orally administrated CAM-W protecting $50 \%$ of animals $\left(E_{50}\right)$ was $<10 \mathrm{mg} / \mathrm{kg}$ (Figure 2). However, these results will have to be extended in more formal toxicity tests, and further experiments will be necessary to produce relaible dose-response curves.

\section{CONCLUSIONS}

Our results showed that CAM-W was $100 \%$ protective to Kunming mice challenged with STEC strains. In regards to safety and toxicity, CAM-W displayed a moderate cytotoxicity against HT-29 cells $\left(\mathrm{IC}_{50}>300 \mathrm{mg} / \mathrm{L}\right)$ and oral administration of a single dose of CAM-W $(5000 \mathrm{mg} / \mathrm{kg})$ did not cause any observable side effects in mice. Notably, CAM-W could barely enter the bloodstream of treated mice. These findings demonstrate the potential value of CAM-W as a treatment for bacterial gastroenteritis and provide a basis for further investigation.

\section{Author contributions}

Z. H., J. S. and C. L. proposed and directed the project. J. S., C. L., L. W., T. X., and M. Q. carried out the experiment. Z. H., J. S., C. L., L. W., T. X., and M. Q. all discussed the results, commented on and revised the manuscript.

\section{ACKNOWLEDGMENTS AND SUPPORT}

This work was supported by National Natural Science Foundation of China (Nos. 31772641), China Postdoctoral Science Foundation (2017M611071), National Key Research and Development Program of China (No. 2016YFD0500501), Key Technologies R \& D Program of Henan Province (162102110171), National Science and Technology Support Program (No. 2012BAD39B01), China Agriculture Research System (No. CARS-42), China Postdoctoral Science Foundation (2015M581220) and the Agricultural Science and Technology Innovation
Program (No. ASTIPIAS07) in China. We wish to thank Dr. Meng Wang for her assistance on conducting the animal experiments.

\section{CONFLICTS OF INTEREST}

There are no conflicts of interest to disclose.

\section{REFERENCES}

1. Malik OA. Role of antimicrobials in the treatment of adult patients presenting to the emergency department with acute gastroenteritis - A mini review. Pak J Med Sci. 2017; 33:488-92. https://doi.org/10.12669/pjms.332.11851.

2. Calandra T. Pathogenesis of septic shock: implications for prevention and treatment. J Chemother. 2001; 13:173-80. https://doi.org/10.1179/joc.2001.13.Supplement-2.173.

3. David SA, Awasthi SK, Balaram P. The role of polar and facial amphipathic character in determining lipopolysaccharide-binding properties in synthetic cationic peptides. J Endotoxin Res. 2000; 6:249-56.

4. Guerra AN, Fisette PL, Pfeiffer ZA, Quinchia-Rios BH, Prabhu U, Aga M, Denlinger LC, Guadarrama AG, Abozeid S, Sommer JA, Proctor RA, Bertics PJ. Purinergic receptor regulation of LPS-induced signaling and pathophysiology. J Endotoxin Res. 2003; 9:256-63. https:// doi.org/10.1179/096805103225001468.

5. Hancock RE, Lehrer R. Cationic peptides: a new source of antibiotics. Trends Biotechnol. 1998; 16:82-8.

6. Ji S, Li W, Zhang L, Zhang Y, Cao B. Cecropin A-melittin mutant with improved proteolytic stability and enhanced antimicrobial activity against bacteria and fungi associated with gastroenteritis in vitro. Biochem Biophys Res Commun. 2014; 451:650-5. https://doi.org/10.1016/j. bbrc.2014.08.044.

7. Boman HG, Wade D, Boman IA, Wahlin B, Merrifield RB. Antibacterial and antimalarial properties of peptides that are cecropin-melittin hybrids. FEBS Lett. 1989; 259: 103-6. https://doi.org/0014-5793(89)81505-4.

8. Ji S, Li W, Xin H, Wang S, Cao B. Improved Production of Sublancin 168 Biosynthesized by Bacillus subtilis 168 Using Chemometric Methodology and Statistical Experimental Designs. BioMed Res Int. 2015; 2015:687915.

9. Sheng-yue J, Wei-li L, Rasheed BA, Meng W, Bin-yun C. Improved production of sublancin via introduction of three characteristic promoters into operon clusters responsible for this novel distinct glycopeptide biosynthesis. Microb Cell Fact. 2015; 14: 201. https://doi.org/10.1186/ s12934-015-0201-0.

10. Chen X, Zhu F, Cao Y, Qiao S. Novel expression vector for secretion of cecropin AD in Bacillus subtilis with enhanced antimicrobial activity. Antimicrob Agents Chemother. 2009; 53:3683-9. https://doi.org/10.1128/AAC.00251-09.

11. Ji S, Li W, Baloch AR, Wang M, Li H, Cao B, Zhang H. Efficient biosynthesis of a Cecropin A-melittin mutant in 
Bacillus subtilis WB700. Sci Rep. 2017; 7:40587. https:// doi.org/10.1038/srep40587.

12. Shimizu K, Asahara T, Nomoto K, Tanaka R, Hamabata T, Ozawa A, Takeda Y. Development of a lethal Shiga toxinproducing Escherichia coli-infection mouse model using multiple mitomycin C treatment. Microb Pathog. 2003; 35:1-9.

13. Gurbay A, Gonthier B, Barret L, Favier A, Hincal F. Cytotoxic effect of ciprofloxacin in primary culture of rat astrocytes and protection by Vitamin E. Toxicology. 2007; 229:54-61. https://doi.org/10.1016/j.tox.2006.09.016.

14. Wadolkowski EA, Burris JA, O'Brien AD. Mouse model for colonization and disease caused by enterohemorrhagic Escherichia coli O157:H7. Infect Immun. 1990; 58:2438-45.
15. Evans DJ Jr, Evans DG, Gorbach SL. Production of vascular permeability factor by enterotoxigenic Escherichia coli isolated from man. Infect Immun. 1973; 8:725-30.

16. Wu M, Hancock RE. Interaction of the cyclic antimicrobial cationic peptide bactenecin with the outer and cytoplasmic membrane. J Biol Chem. 1999; 274:29-35.

17. Jacob HJ, Sigmund CD, Shockley TR, Gross KW, Dzau VJ. Renin promoter SV40 T-antigen transgenic mouse. A model of primary renal vascular hyperplasia. Hypertension. 1991; 17:1167-62. 